Corinne D'Antonio

(Sapienza University of Rome, Italy)

\title{
BUDDHIST SANSKRIT AND THE INVENTION OF “GENDER" BY PRE-MODERN JAPANESE GRAMMARIANS
}

The present paper aims to analyse the influence Sanskrit studies exerted on Japanese Buddhist scholars in their attempts to identify the category of grammatical gender in Japanese. After a short review of the first Chinese and Japanese accounts of Sanskrit morphology, the interpretation of the monk Sengaku (13 ${ }^{\text {th }}$ cent.) will be considered, with a special focus on the formal and semantic criteria he used in assigning "genders" to Japanese nouns. Building on the model of the Sanskrit nominal declension, he analyses a set of Japanese nouns that show an alternation in the terminal vowel, while preserving the semantic value (like amalame 'heaven'): he considers "masculine" the $-a$ variant, while "feminine" all the other variants. On specific occasions he is also guided by a purely semantic criterion, i.e. the sex of the referent. Later Japanese grammarians adopted a very similar formal perspective, which generally revealed an imperfect knowledge of Sanskrit. It is also claimed that another criterion that was taken into consideration by the Japanese monks dealing with Sanskrit and Japanese grammars was rooted in some esoteric Buddhist theories that considered "masculine" and "feminine" different syllables of siddham, the sacred alphabet of the Buddhist scriptures.

Keywords: Sanskrit grammar, Japanese grammar, gender, Buddhism.

$$
\begin{array}{r}
\text { Корин Д'Антонио } \\
\text { (Университет Сапиенца, Рим, Италия) }
\end{array}
$$

\section{Буддийский санскрит и изобретение грамматического «рода» средневековыми японскими грамматистами}

В статье рассматривается влияние санскрита на средневековых японских грамматистов, пытавшихся установить категорию грамматического рода в японском языке. За кратким обзором средневековых китайских и японских свидетельств о санскритской морфологии, следует подробный анализ грамматических построений японского монаха Сэнгаку (13 век), который первым сформулировал процедуру определения «рода» японских существительных, причем он руководствовался как семантическими, так и чисто формальными критериями. Следуя модели именного склонения санскрита Сэнгаку рассматривает несколько японских существительных, которые показы- 
вают чередование конечных гласных, не влияющих на семантическое значение (например, amalame 'небо'): варианты с конечным $a$ он приписывает мужскому роду, а варианты с иной конечной гласной женскому. В отдельных случаях он также руководствуется и чисто смысловым критерием - полом референта. Японские грамматисты более поздних эпох подходили к проблеме рода в основном формально, при этом показывая довольно несовершенное знание санскрита. Кажется релевантным в этой связи и фактор, связанный с эзотерическими буддийскими теориями, которые приписывали «мужественность» и «женственность» разным слогам азбуки сиддхам священного письма китайских и японских буддистов.

Ключевые слова: санскритская грамматика, японская грамматика, грамматический род, буддизм.

\section{Introduction}

It is well-known that the introduction of Buddhism in China allowed the study of Sanskrit to spread in East Asia. Initially, Chinese and Japanese Buddhist monks were not exceptionally learned in the Sanskrit language and the Chinese translations of the Indian Buddhist texts were performed - especially at the beginning of the Buddhist era - by Indian and Central Asian monks, rather than by indigenous scholars (cf. Van Gulik 1956; Chaudhuri 1998; see also Zürcher 1959 on the translation process in the Chinese Buddhist monasteries).

Nonetheless, the influence siddham studies $^{1}$ - as the Sanskrit studies were called in East Asia - had on the development of a linguistic thought in China and Japan was undoubtedly extensive and eventually affected many aspects of the indigenous grammatical traditions, in particular phonetic studies. Thus, while in China siddham influenced the description of the sounds and the so-called fănqiè system, the Japanese Buddhist scholars borrowed the Indian arrangement of the syllables (varnamāla $)^{2}$ and applied it to the indigenous syllabaries.

\footnotetext{
${ }^{1}$ Siddhamatrkka 'established matrix of letters', or simply siddham, was the conventional name of a late Indian brahmi $\bar{s}$ script from the $6^{\text {th }}$ century CE, that became known in East Asia. The term siddham in China and Japan identified both the script and the language of the Buddhist texts (cf. Van Gulik 1956).

${ }^{2}$ The varnamāla is said to have entered China for the first time through the translations of the Mahāparinirvāna sūtra around the beginning of the $5^{\text {th }}$ century CE (Chaudhuri 1998: 14). From China, it was later brought to Japan.
} 
Morphological aspects of the siddham influence in East Asia, on the other hand, have drawn much less attention from modern scholars. However, Sanskrit morphology also had an influence of some relevance on the Buddhist monks' grammatical insights.

\section{The first morphological accounts}

A small number of Chinese scholars recorded sporadic accounts on Sanskrit morphology, and these scattered data were brought to Japan along with the Buddhist canon. The Chinese approach to Sanskrit morphology was mostly descriptive. Xuánzàng (602-664) was one of the first Chinese monks to travel to India and left some accounts of Sanskrit verbal and nominal inflection (cf. Chaudhuri 1998: 29-30) ${ }^{3}$. As regards the nominal inflection, he identifies three genders, respectively called nánshēng 'masculine', nü̈shēng 'feminine', fêinán fêinü shēng 'neuter' (the last one literally translated as 'neither masculine, nor feminine'). He also noticed three numbers ('singular', 'dual', 'plural'), and eight cases. Similarly, Făzàng (643-712), after giving a semantic explanation of the eight Sanskrit cases, identifies three genders, i.e. masculine, feminine and neuter, and three numbers ${ }^{4}$.

When these accounts of Sanskrit grammar arrived in Japan, Japanese scholars initially adopted such a descriptive approach to explain Sanskrit features. Thus, the influential Buddhist monk Annen (841-915) lists the eight cases, the three gender values and the three numbers, giving the declension of words like purușa 'person' and buddha as examples. Medieval Japanese scholars, on the other hand, exhibit a more creative approach to Sanskrit grammatical theory: they try to apply the features they noticed in Sanskrit to the indigenous language, using Sanskrit as an explicative model. In fact, the Sanskrit category of nominal case was at first explained by drawing a peculiar parallelism with Japanese verbal inflection (cf. Kondo 1992). Only in modern times were nominal cases definitively correlated to Japanese nominal particles, as bearing the same syntactical functions. Perhaps even more surprising is the application of the category of gender to Japanese, according to a formal criterion based on word-final vowel alternations, and also on the Buddhist doctrinal approach to language.

\footnotetext{
${ }^{3}$ See the original Chinese text at SAT daizōkyō T2053_.50.0239b12 ff., translated in Beal (1911).

${ }^{4}$ See the original text at SAT daizōkyō T1733_.35.0149a29 ff. For a survey see D’Antonio, Keidan (2022).
} 


\section{Sengaku and his description of Japanese gender}

Japanese has never had grammatical gender in any of its historical phases. That is to say, it never had any nominal classification based on the agreement the nouns take (cf. the general definition by Corbett 1991: 105; on Japanese cf. Shibatani 1990). Yet, some Japanese Buddhist scholars, influenced by their (although limited) knowledge of Sanskrit, tried to identify "genders" in Japanese as well.

The Buddhist monk Sengaku (1203-?) is one of the first scholars to have adopted this approach. He drew a vast influence from the studies of siddham, for both his phonetic and morphological insights, and attempted to explain some properties of the Japanese language through Sanskrit grammatical categories in his 20-volume commentary on the Man'yōshu poetic collection, called Man'yōshū chūshaku, compiled in 1269 (cf. Yamada 1944: 242; Okazaki 2011) ${ }^{5}$.

As regards gender, he argues that in Japanese, as in Sanskrit, a difference can be drawn between masculine gender (nansei) and feminine gender (nyosei). Curiously, he does not mention the neuter gender (see his opera omnia, Sasaki 1925: 28), though this value was mentioned in the descriptions of Sanskrit by Chinese and Japanese scholars before him. Sengaku argues that the masculine gender is expressed by the syllables ending in $-a$, i.e. $a, k a, s a, t a$, $n a, h a^{6}, m a, y a, r a, w a$. The feminine gender, on the other hand, is expressed by the syllables $i, k i, s h i, c h i, n i, h i, m i, r i, w i$, but also by the syllables "after them" (cf. also Yamada 1944: 235; this approach has been also dealt with by Mabuchi 1962).

To understand Sengaku's statement a brief introduction to the organisation of the Japanese syllabaries may be needed. As mentioned above, the Japanese syllables are arranged in a chart, called gojūonzu 'table of fifty sounds', which draws its ordering from the traditional Indian alphabetic order (the varnamāla $)$. In fact, the phonetic principles governing the Indian varnamāla (vowels at the beginning, followed by the consonants ordered by manner and place of articulation) are visible in the Japanese arrangement as well.

\footnotetext{
${ }^{5}$ Man'yōsh 'Collection of ten thousand leaves' is the oldest Japanese poetic anthology that has survived to the present day. It is usually believed to have been compiled around $759 \mathrm{CE}$, but it includes poems composed from the 6th century onwards.

${ }^{6}$ The fricative $h$ of contemporary Japanese had at that time a plosive realization $p$, see also below.
} 
The Japanese alphabetical order shows firstly the vowels, ordered by the same principles as the Indian tradition $(a, i, u, e, o)$. The order of the consonants follows the Indian one as well, with some modifications: $k-, s^{-}, t-, n-, h-, m-, y-, r-, w-$ each followed by the five vowels ( $k a, k i, k u, k e, k o$, and so forth). The Japanese modifications to the Indian ordering are due to the following reasons: 1) Indian languages have phonemes that Japanese does not have, e.g. retroflexes, and aspirated consonants; 2) Old and Middle Japanese had a different phonemic inventory than contemporary Japanese, e.g. the phoneme $h$ had not undergone fricativisation yet and had a plosive realization in Old Japanese; 3) Japanese did not have special symbols for the voiced stops, which were represented by diacritics put on the symbols for the voiceless counterparts. Therefore, the Japanese sequence of consonants is produced by excluding from the Indian varnamāla all the "unused" phonemes. Moreover, as stated above, the present-day $h$ is to be understood as $p$ (which explains its location before $m$, as in the varnamāla ), while the peculiar position of $s$ could be explained by supposing that Old Japanese $s$ had alveolar but also palatal fricative or affricate allophones (though the exact reconstruction is still debated, cf. Frellesvig 2010: 36 ff.; Miyake 2003: $177 \mathrm{ff}$.): it would therefore fall into the category of palatals, which follow the velars in the varnamāiā.

The chart of the fifty sounds in Japan, initially only an ordered list of sounds, was later arranged in a grid. Today, the grid is made of ten columns, which are called by the first syllable (i.e. $a$-column, $k a$-column, sa-column, and so forth), and five rows, named after the respective vowel (i.e. $a$-row, $i$-row, and so forth). Thus, the first column ( $a$-column) comprises all the simple vowels, the second column ( $k a$-column) the syllables $k a, k i, k u, k e, k o$, and so forth. On the other hand, the first row ( $a$-row) encompasses all the syllables ending in $-a$, the second ( $i$-row) those ending in $-i$ etc.

Therefore, what Sengaku seems to imply is a formal criterion, according to which the masculine gender would be expressed by nouns ending with one of the syllables of what we call $a$-row (-a, $k a,-s a$ and so forth), whereas the feminine gender would be assigned to all the nouns that do not end with $-a$, i.e. all those nouns ending with syllables belonging to the $i$-row, the $u$-row, the $e$-row and the $o$-row (cf. also Yamada 1944: 241). The assigning of masculine to the $a$ is obviously reminiscent of Sanskrit declension, where the stems terminating with an $a$ are masculine (or neuter, but Sengaku ignores the neuter). 


\section{Sengaku's examples}

Among the several examples Sengaku offers in favour of his hypothesis we can list the following (Sengaku's formulations are maintained):

1. iso as a feminine word, as opposed to the masculine isa (iso kuni 'unknown region', MYS1.50, p. 48,);

2. ama and ame, both meaning 'heaven, sky': ama would be masculine, while ame feminine (in the dvandva compound ametuti 'heaven and earth', the word ame is feminine, p. 96-97);

3. other pairs with the same meaning, such suge/suga 'sedge', sake/saka 'alcohol', takeltaka 'bamboo', kaze/kaza 'wind': the -a ending words are assigned the masculine gender (p. 107);

4. the word yoru 'night' is assigned the masculine gender when it is becomes yora (kono yora 'this night', MYS4.548, p. 141).

5. the Classical Japanese pair wagaseko 'my beloved (male)' and wagimoko 'my beloved (female)': as wagimoko needs to refer to a woman, it shows the vowel $i$ in the second syllable, and therefore this word needs to have feminine gender value; conversely, wagaseko has a male referent, thus it needs to be assigned the masculine gender (p. 175, cf. also Yamada 1944: 241).

As can be inferred from the examples, Sengaku seems to assign different gender values mostly to alternating pairs bearing the same meaning, i.e. amalame, takaltake etc. (with the exception of wagaseko/wagimoko; see below). In fact, Yamada (1944: 239), in his analysis on Sengaku's work, correctly suggests that the difference between masculine and feminine gender seems to be postulated by Sengaku especially when he finds two alternating forms, distinguished by the vowel of the last syllable, whereby the variant in $-a$ is considered masculine, and all the others feminine. For instance, a word ending in - $r a$ may be intended as masculine when it can alternate with a form ending in -re or -ru (e.g. the word tsura as opposed to tsuru, both meaning 'string'). However, it may also be possible that Sengaku only exemplified his theory by these alternating stems, but aimed theoretically to apply gender values to every Japanese noun.

Thus, it seems that in Sengaku's theory gender has two notable features:

1. it is assigned on formal principles, i.e. phonological basis (- $a$ is masculine, non $-a$ is feminine); 
2. it may be assigned to every noun, but it is particularly exemplified by alternating stems.

It is worthwhile highlighting that these competing forms bear the same meaning, thus the presumed opposition between the masculine gender ama 'heaven', and the feminine gender ame 'heaven' is purely formal. Diachronically, the presence of such competing forms is believed to be due to the contraction of Proto-Japanese diphthongs. In fact, it is generally assumed that the $-a$ ending stem is the original form. Conversely, Old Japanese $-e$ ending has a secondary origin, i.e. monophthongisation of the diphthongs *ay and * yy (whose approximant's origin is still debated, cf. Frellesvig 2010: 44 ff.; Frellesvig, Whitman 2004: 284). This gave rise to alternations, curiously called "apophonic" in contemporary scholarship, in which the original $-a$ form is generally used in derivation, while the $-e$ form occurs mostly in word final position. The same phenomenon underlies other Japanese competing forms like kami/kamu- 'spirit', ki/ko- 'tree', se/so- 'back', whose alternations date back to Old Japanese but are still frequently used even in contemporary Japanese (cf. Irwin, Labrune 2020).

Conversely, both formal (the final vowel) and semantic (the sex of the referent) reasons seem to determine the gender assignment in the case of the compounds wagaseko and wagimoko, both meaning 'my beloved' (male and female, respectively). Sengaku argues that wagaseko is masculine because its referent is a man, while wagimoko is feminine because its referent is a woman and shows the vowel $i$ in the second syllable. As concerns the word formation, both forms show the first person pronoun wa followed by the possessive particle $g a$, in turn followed by two nominals: seko, which is composed of se 'husband, elder brother' and the diminutive suffix $k o$, and imoko, formed by imo 'wife, younger sister' and the same diminutive suffix $k o$ (cf. Vovin 2005: 216). Thus, in the case of wagimoko, a typical phenomenon of vowel deletion occurs: $-a$ is elided before $i$-, that is wa ga imoko $>$ wagimoko (cf. Frellesvig 2010: 39-40). Sengaku seems to interpret the presence of the syllable $g i$, as opposed to $g a$, as a marker of the feminine; moreover, gender agrees with the sex of the referent. However, this is the only example in which Sengaku seems to use a semantic explanation, so this principle may not hold in other cases (e.g. he does not mention the terms for 'man' otoko, and 'woman' onna, which would contradict his theory). The other examples he mentions abide by the formal principle only. Later scholars continued this formal approach. 


\section{Gender values in Keichū and Shōten}

Sengaku's application of principles governing the Sanskrit language to Japanese was borrowed by scholars of the Edo period (1603-1867), who explicitly referred to siddham and even to specific Sanskrit examples.

Keichū (1640-1701) was both a Buddhist monk and an eminent kokugaku 'national studies' scholar, who worked both on siddham and on the Old Japanese language. In his Waji shöranshō 'Corrections to mistakes in Japanese characters' (1693, published in 1695), he challenged the standard usage of kana syllabaries at that time and proposed a different approach based on Sanskrit (cf. Seeley 1975; Chaudhuri 1998: 112). In fact, influenced by the fact that a consonantal grapheme in siddham script represents the consonant plus the inherent vowel $a$ (other vowels being expressed by diacritics), he established a specific Japanese character for each Japanese syllable ending in $-a$, and tried to reinterpret small graphic fragments of some Japanese characters as diacritics for the other vowels. Moreover, he hints at grammatical features of the Sanskrit language. As regards gender, he borrows Sengaku's idea that alternating Japanese stems bearing the same meaning, like ama/ame, may be assigned Sanskrit-like gender values. First, he explains that in Sanskrit the word for 'heaven, deity' (i.e. Japanese ame/ama) is deva 'deity', which Keichū transcribes phonetically using Japanese logograms reading deiba ${ }^{7}$. When $i$ is added to the last syllable, it becomes deibi (i.e. Sanskrit devī). Keichū states that deiba $($ deva) is the word for a masculine deity, while deibi $(\operatorname{dev} \bar{\imath})$ is the word for a feminine deity. Similarly — he continues — in Japanese ama 'heaven' is masculine while ame 'id.' is feminine.

Keichū does not go into detail about gender, nor does he show any other examples. Also, he does not write the Sanskrit words in siddham script. Shōten or Seiten (1663-1747), on the other hand, in his Wago renjōshu 'Collection on Japanese sandhi' (1735) writes the word deva in siddham script, glosses it in Japanese syllabary, and assigns it the masculine gender. When the siddham diacritic for $i$ is added, it becomes devi (written in siddham script as well, with short $i$ ): this is a feminine word and is used for a female deity, he says. Similarly — he adds — when we say ama no gawa 'milky way, lit. river of heaven', ama ends in -ma, and it is masculine

\footnotetext{
${ }^{7}$ See pp. 33-34 in the first volume of Keichū's Waji shōranshō.
} 
gender. When we say ame ga shita 'under the sky', the ending -me identifies the feminine gender ${ }^{8}$.

Lastly, we may introduce Jiun (1714-1804), who compiled a work that comprised many of the data available on Sanskrit and siddham at that time, called Bongaku Shinryō 'Guide to Sanskrit studies" ${ }^{9}$. He mentions the gender category in Sanskrit, but does not discuss it in detail. He only addresses the words nara 'man' and nāri 'woman' (cf. Chaudhuri 1998: 82-83).

\section{Conclusive remarks: the doctrinal issue}

It is evident that the assignment of gender values to Japanese nouns by Buddhist monks relies heavily on what they were able to infer concerning Sanskrit gender values. Japanese monks noticed Sanskrit masculine/feminine alternation in such nouns as deva/dev $\bar{\imath}$ and nara/nāri (with no neuter counterpart), and assumed that the same mechanism could apply to Japanese. Therefore, they identified alternating nouns like amalame in Japanese, and tried to explain this phenomenon through the lens of Sanskrit grammar. This may be the reason for which gender assignment by Buddhist scholars seems to be related especially to formal aspects: only the $-a$ ending identifies a masculine stem (being deva and nara masculine). Moreover, Shōten, in transcribing Sanskrit in siddham script, writes devi with a short $-i$ (instead of $d e v \bar{l}$, the correct form in Sanskrit). This seems to reveal that Japanese monks might have had a limited knowledge of Sanskrit declension and that their assignment of gender values to Japanese nouns may rather rely on the sporadic words and rules they may have encountered in the course of their study ${ }^{10}$.

In order to understand Japanese Buddhists' accounts of gender, a different aspect may need to be considered, namely the underlying profound meaning Buddhism bestows on siddham syllables, as

\footnotetext{
${ }^{8}$ The original text is available in Fukui's Kokugogaku taikei, vol. 3.

${ }^{9}$ For an introduction see Van Gulik (1956: 133ff.).

${ }^{10}$ Generally speaking, the identification of $-a$ as inherently masculine and of $-i$ as inherently feminine is a major simplification of the real state of affairs in Sanskrit. To start with, $-a$ is not an ending, but a thematic vowel. It is reserved for masculine but also neuter nouns. The other thematic vowels, some of which could eventually function also as endings, were not so strictly correlated to a specific gender value. A typical feminine marker was the long $-\bar{i}$, not the short $-i$, which could also be masculine. Other thematic vowels (or endings) could be assigned to different genders as well. See Whitney (1896: 99 ff.) on Sanskrit declension.
} 
discussed both in Chinese and Japanese commentaries ${ }^{11}$. In fact, the Chinese monk Yī Xíng (683-727) examined the interpretation of Sanskrit syllables in his Commentary on the Mahāvairocanābhisambodhi sūtra (a Buddhist sacred text) ${ }^{12}$. He stated that syllables ending in $-a$ convey the idea of wisdom and masculinity, while the other syllables, with diacritical marks on them, signify concentration and femininity (cf. the translation by Dreitlein 2016: 142-143; cf. also Chaudhuri 1998: 33). Kükai (774-822), one of the most influential Japanese Buddhist scholars, seems to have borrowed a similar idea in his Kongōchōgyō kaidai (a text dealing with Sarvatathägatatattvasamgraha, another sütra of the Buddhist Canon) in claiming that the "first letter" (i.e. $a$, being listed first among the vowels according to the Indian varnamāla $)$ is the base form and the mark of the masculine, while the following (letters, i.e. vowels) are feminine. Thus, in the esoteric Buddhist environment, $a$ is considered masculine, while all the other vowels feminine. The same reasoning seems to emerge from Sengaku's and later Buddhist scholars' accounts, which may have been influenced by such interpretations of the siddham syllables in the Buddhist esoteric context.

All these attempts to apply such alien grammatical categories as gender to Japanese help us to better understand the importance Sanskrit, but also Buddhist thought in general, had in shaping the linguistic tradition in Japan. In fact, though it may be considered wrong from a contemporary point of view (as already recognised by Yamada 1944), this approach by Japanese Buddhist scholars seems to reveal a nascent meta-linguistic reflection on their own language and on the possible similarities between Sanskrit and Japanese, together with a good degree of grammatical creativity. But, moreover, it also reveals the importance of the esoteric Buddhist theories concerning the siddham script and the Sanskrit language to the early Japanese linguistic tradition.

\section{Bibliography}

Chaudhuri, S. K. 1998: Siddham in China and Japan. Sino-platonic papers 88: $1-124$.

Corbett, G. G. 1991: Gender. Cambridge: CUP.

\footnotetext{
${ }^{11}$ This is not a specific East Asian feature, however. It is already found in India and in the neighbouring Buddhist traditions (e.g. in the Kothanese tradition, cf. Emmerick 1968: 121). Cf. Payne (2018) for a general introduction.

${ }^{12}$ The original text is available at SAT T1796_.39.
} 
D’Antonio, C., Keidan, A. 2022: The adventures of Pānini's grammar in China and Japan: the case of the käraka/vibhakti system. Rivista degli Studi Orientali 95 (Forthcoming).

Dreitlein, T. E. 2016: An annotated translation of Kūkai's Kongōchōgyō kaidai. Bulletin of the Institute of Esoteric Buddhism and Buddhist Culture 29: 136-186.

Emmerick, R. E. (ed.) 1968: The Book of Zambasta - A Kothanese poem on Buddhism. London: OUP.

Frellesvig, B. 2010: A History of the Japanese Language. Cambridge: CUP.

Frellesvig, B., Whitman, J. 2004: The vowels of proto-Japanese. Japanese Language and Literature 38: 281-299.

Fukui, K. (ed.) 1938: Kokugogaku Taikei. Tōkyō: Kōseikaku.

Irwin, M., Labrune L. 2020: The Productivity of Apophony in Japanese: an Experimental Approach. Bulletin of Graduate School of Social \& Cultural Systems at Yamagata University 17: 41-52.

Keichū 1695: Waji Shōranshō. Tōkyō.

Kondo, Y. 1992: Kōzanjibon Hattenjōshō wo megutte. In: Kōzanji Tenseki Monjo Sōgō Chōsadan (eds.). Kōzanji tenjaku monjo sōgō chōsadan kenkyūhōkoku ronshū Heisei 3 nendo. Tōkyō, 95-107.

Mabuchi, K. 1962: Nihon ingakushi no kenkyū. Tōkyō: Nihon gakujutsu shinkōkai.

Miyake, M. H. 2003: Old Japanese: a Phonetic Reconstruction. London: Routledge.

Okazaki, M. 2011: Chūsei kagaku ni okeru gengo ishiki - Sengaku "Man'yōshū chūshaku" wo megutte. In: Maeda M. (ed.) Chūsei no gakugei to koten chūshaku, Tōkyō: Chikurinsha, 261-286.

Payne, R. K. 2018: Language in the Buddhist Tantra in Japan - Indic Roots of Mantra. London: Bloomsbury.

Sasaki, N. 1925: Sengaku zenshū, Tōkyō: Kokin shoin.

Seeley, C. 1975: The "Waji shōran-shō" of Keichū and its position in historical kana usage studies. PhD Dissertation. SOAS University of London.

Shibatani, M. 1990: The Languages of Japan. Cambridge: CUP.

Van Gulik, R. H. 1956: Siddham: An Essay on the History of Sanskrit Studies in China and Japan. New Delhi: Jayyed Press.

Vovin, A. 2005: A Descriptive and Comparative Grammar of Western Old Japanese. Part. 1. Folkestone: Global Oriental.

Whitney, W. D. 1896: Sanskrit Grammar: including both the classical language, and the older Dialects of Veda and Brahmana. Leipzig: Breitkopf \& Hartel.

Yamada, Y. 1944: Kokugogakushi. Tōkyō: Hōbunkan.

Zürcher, E. 1959: The Buddhist Conquest of China - The Spread and Adaptation of Buddhism in Early Medieval China. Leiden: Brill. 